\title{
PANCASILA ANTARA AKUMULASI INFORMASI DAN PARADIGMA KEBANGSAAN
}

Oleh:

Toni \& Faisal*

Email; progresif_1shp@yahoo.com

\begin{abstract}
Abstrak
Pancasila in relation to the law always has a general tendency that Pancasila is placed as the highest part of the Indonesian legal pyramid model. Pancasila becomes contemplation, concerning efforts to put Pancasila at a standstill in accumulating information or continuing it as a national paradigm and if Pancasila is expected to shape the nation's way of thinking, then it should be like what we are behaving in a national context. in fact, Pancasila is an authentic feeling of the national paradigm which must be continually maintained and pass on those values to logical consciousness with intuitive reflection.
\end{abstract}

Key Word : Pancasila, Information Accumulation, Nationality Paradigm

\section{A. PENDAHULUAN}

Topik diatas bukan sesuatu yang muncul secara tiba-tiba, tetapi hadir dalam perjumpaan penulis dengan tulisan Prof Liek Wilardjo yang berjudul Ilmu: Antara Sikap dan Pengetahuan dalam buku "Realita dan Desiderata”. Pada bagian penutup Prof Liek Wilardjo menuturkan ilmu dan pengetahuan bukan sekedar akumulasi informasi, lebih dari itu dapat membentuk cara berfikir. ${ }^{1}$

Dari arus perkembangan filsafat sendiri lahirlah positivisme yang dirintis oleh Aguste Comte (1798-1857). Positivisme menjadi paham dominatif dalam

*Dosen Fakultas Hukum, Universitas Bangka Belitung

${ }^{1}$ Liek Wilardjo, 1990, Realita dan Desiderata, Yogyakarta, Duta Wacana University Press, hlm. 168. perkembangan pengetahuan modern. ${ }^{2}$ Harus disadari bahwa positivisme bukan sekedar informasi yang merubah realitas pada waktu itu dengan paham rasionalismenya, tapi juga menawarkan sesuatu yang khas dan berciri. Positivisme membentuk cara berfikir objektif dan bebas nilai. Oleh karena itulah dikatakan, di dalam (paradigma) positivisme ada dikotomi yang tegas antara fakta dan nilai, dan mengharuskan peneliti mengambil jarak terhadap realitas dengan bersikap netral. ${ }^{3}$ Dengan maksud itu, sulit untuk menerima jika pengetahuan

\footnotetext{
2 F. Budi Hardiman, 2013, Kritik Ideologi "Menyikap Pertautan Pengetahuan dan kepentingan Bersama Jurgen Habermas, Yogyakarta, Kanisius, hlm. 26.

${ }^{3}$ Adji Samekto, 2012, Ilmu Hukum dalam Perkembangan Pemikiran Menuu PostModernisme, Lampung, Indepth Publishing, hlm. 32
} 
hanya berhenti pada pengertian informasi semata-mata, akan tetapi ia membawa misi ideologis yaitu membentuk cara berfikir terhadap realitas yang akan dijelaskannya.

Pembacaan di atas menjadi penting bila melibatkan Pancasila menjadi perenungan, menyangkut upaya untuk mendudukkan Pancasila apakah berhenti pada akumulasi informasi atau meneruskannya sebagai paradigma kebangsaan? dan bila Pancasila diharapkan membentuk cara berfikir bangsanya, lalu semestinya seperti apakah kita besikap dalam konteks kebangsaan?

\section{B. PEMBAHASAN}

\section{Kontekstualisasi Pancasila}

Saat ini jika kita berbicara mengenai Pancasila yang pada kaitannya dengan hukum maka selalu memiliki kecenderungan umum bahwa Pancasila ditempatkan sebagai bagian yang paling tinggi dari model piramida hukum Indonesia. Sebagaimana hal ini dijelaskan oleh Shidarta bahwa Pancasila menjadi bintang pemandu atau litstern, yang lapisan-lapisan materinya berisi subtansi hukum dan tiang kerangkanya struktur hukum, serta lingkungan kehidupannya adalah budaya hukum. ${ }^{4}$ Dardji

Darmodihardjo menempatkan

Pancasila sebagai sumber hukum dengan menggambarkan gagasan dari Hans Kelsen tentang Grundnorm atau norma dasar sebagai sumber dari segala sumber hukum Indonesia. ${ }^{5}$ Sementara Arif Sidharta menjelaskan tentang cita hukum yang berakar pada Pancasila, yang secara formal dicantumkan dalam Pembukaan Undang-Undang Dasar $1945 .^{6}$

Dalam kehidupan nasional Pancasila telah diakui sebagai salah satu konsensus dasar bangsa Indonesia. Hal ini dapat dilihat dari sejarah proses pembuatan dan penggalian Pancasila sebagai ideologi negara, dasar negara, atau pandangan hidup bangsa. Bagaimana proses perdebatan berlangsung yang kemudian melahirkan kesimpulan sebagaimana dijelaskan Soekarno sebagai inti dari kepribadian atau lima mutiara yang sudah berabad-abad

4 Anthon Susanto, 2010, Ilmu Hukum Non Sistematik "Fondasi Filsafat Pengembangan Ilmu Hukum Indonesia", Yogyakarta, Genta Publishing, hlm. 294.

${ }^{5}$ Ibid.

${ }^{6}$ Cita hukum (rechtsidee) mengandung arti bahwa pada hakekatnya hukum sebagai aturan tingkah laku masyarakat yang berakar pada gagasan, rasa, karsa, cipta dan fikiran dari masyarakat itu sendiri. Jadi cita hukum itu adalah gagasan, karsa, cipta dan fikiran berkenaan dengan hukum atau persepsi tentang makna hukum. Ibid. 
tertanam dalam kehidupan bangsa Indonesia.

Pada masa-masa orde baru Pancasila menjadi semacam kata-kata ampuh yang digunakan untuk mendukung propaganda politik, dengan mengangkat Pancasila menjadi satu-satunya asas kehidupan bernegara. Tidak cukup sampai disitu, proses indoktrinisasi juga terus berlangsung melalui berbagai penataran P4, dan kegiatan Seminar Pancasila yang harus diikuti oleh peserta didik formal di sekolah sampai perguruan tinggi. Setelah orde baru perlahan perhatian terhadap Pancasila mulai berkurang. Padahal jika melihat pada masa sebelumnya hampir setiap dimensi kemasyarakatan memiliki label Pancasila, sebut saja karya teoritik Mubyarto berkenaan dengan Sistem Ekonomi Pancasila, bahkan sampai membicarakan bola sekalipun dengan argumen "Sepakbola Pancasila".

Orde baru menjadi kesan puncak ketidakberuntungan pengembangan nilai-nilai Pancasila dalam kehidupan sehari-hari. Pancasila tampil lebih merupakan habitus formal kenegaraan daripada menjadi sesuatu yang kontekstual dan otentik. Pembicaraannya hanya informasi yang kurang mendapat sentuhan penjiwaan, hasil yang di dapat tentu sebatas narasi normatif. Bila hal yang demikian terjadi, betapa sulit kita dapat menyadari apa yang pernah dikatakan oleh Notonagoro bahwa Pancasila merupakan karya agung pendiri bangsa melalui hasil pemikiran elektis inkorporasi. Pandangan itu melihat karya besar Pancasila setingkat dengan pemikiran besar lainnya, seperti liberalisme, sosialisme, komunisme, pragmatisme, sekularisme, dan paham-paham lainnya.

Kemudian setelah bangsa Indonesia melakukan reformasi dan melimpahkan salah kaprah pengembangan Pancasila kepada penguasa orde baru, setelahnya terjadi pengidentifikasian cara pengembangan baru dengan membangkitkan kembali Pancasila dengan istilah empat pilar kebangsaan (Pancasila, UUD 45, NKRI, Bhienika Tunggal Ika). Terlepas hadirnya kritik terhadap konsep empat pilar kebangsaan yang dikembangkan oleh MPR-RI dimana terdapat kerancuan berfikir ketika mendudukan Pancasila sebaga pilar yang sejajar dengan lainnya, akan tetapi harus juga diakui Pancasila sudah mulai kembali hadir dalam perbincangan akademik, 
ekonomi, politik, hukum dan aspek lain.

Hal sangat sulit sekali diterima, ketika Pancasila sebagai pemandu dalam kehidupan berbangsa dan bernegara ternyata tak berbanding lurus dengan pelembagaan nilainya secara apik. Barangkali pasang surutnya problem pelembagaan Pancasila bukan disebabkan oleh kelemahan pada nilai-nilai yang terkandung di dalamnya, melainkan pada inkonsistensi dalam penerapannya.

Sikap batin moralitas bangsa Indonesia tentu tak dapat dipisahkan dari Pancasila. Mengingat Pancasila memiliki landasan moral dalam menghadapi keadaan-keadaan yang menyertai perjalanan hidup bangsanya. Sikap moral itulah yang pada umumnya dijadikan pedoman bagi manusia Indonesia ketika mengambil suatu tindakan, dan renungan terhadap kehidupan problem kebangsaan sehari-hari.

Artinya, negara hukum Indonesia akan selalu mengalami kemandegan tujuan konstitusionalnya apabila aspek hukum dan politik begitu dominan tanpa dibina oleh landasan moral. Dengan begitu, prinsip moral menjadi pancaran dan filsafat konseptual dalam menampilkan negara hukum yang dibentuk berdasarkan legitimasi hukum dan politik. Relasi ketiganya tidak dapat dipahami sebagai antinomi yang berjarak, walaupun aspek moral menjadi nilai fundamental yang utama sebagai konsep etik dari hukum dan politik . Artinya hukum dan politik tidak berawal dari dirinya sendiri, melainkan dari prinsip moral manusia dan bangsanya.

\section{Pancasila (Perasaan Otentik)}

\section{Paradigma Kebangsaan}

Soekarno sebagai pencetus Pancasila, melontarkan cita-cita keadilan sosial amat tegas sebagai wujud perlawanan terhadap belenggu dominasi ketidakadilan yang ia rasakan bersama rakyat Indonesia. Ekspresi sebuah pernyataan keadilan sosial mesti menjadi bagian yang terus menerus diperjuangkan. Konsepsi keadilan sosial tak dapat dilepaskan dari sikap batin nilai-nilai Pancasila. Ia harus senantiasa di jiwai oleh Pancasila, tak dapat dilepaskan pengertiannya dalam pusaran pasar bebas, globalisasi, atau dominasi kapitalisme. Justru keadilan sosial disini harus memiliki motif Pancasila.

$$
\text { Merawat keadilan sosial }
$$
sebagai basis dari Pancasila merupakan suatu hal yang tak dapat dihindari. Untuk itu, kiranya perlu 
menguraikan dan menjabarkan bagaimana keadilan sosial yang disifati oleh Pancasila, yaitu paradigma Ketuhanan, Kemanusiaan, dan Demokrasi.

Hendaknya Pancasila itu harus diterima sebagai paradigma ${ }^{7}$ kebangsaan yang mengandung sumber nilai, kerangka pikir, orientasi dasar, sumber asas serta arah dan tujuan bernegara. Persemaian ide kebangsaan yang berangkat dari nilai spiritualitas, nilai kultural, nilai keadilan, nilai kesatuan dan paham pembebasan di lanjutkan dengan upaya kristalisasi pada Pancasila, memberikan perspektif dasar yang membawa kita kepada kebutuhan untuk melihat sosok Indonesia sebagai bangsa yang mengekspresikan paradigma kebangsaan itu.

Dalam kehidupan sehari-hari Pancasila tidak akan hidup bila diserahkan begitu saja pada rasio instrumental. Bila hal demikian terjadi, akan terasa sia-sia Pancasila sebagai paradigma otentik yang diterima dan dijalankan dengan nirmakna, atau informasi yang sama sekali tak mampu menghadirkan

7 Paradigma adalah kumpulan tata nilai yang membentuk pola pikir sebagai titik tolak pandangan hidup. Paradigma cukup mendapat tempat dalam ulasan Thomas Khun dalam karyanya The Structure of Scientific Revolution. paham kebangsaan yang memberikan ciri dan karakter baik itu cara berfikir maupun sikap dalam kehidupan nyata. Apalagi di tengah kehidupan masyarakat modern kekinian, akan menjadi bangsa yang terombangambing bila tak hadir dengan paradigma kebangsaannya. Tak ada lagi yang dapat menjadi pertaruhan dalam pertahanan diri bila tidak berpijak pada perasaan otentik kita sendiri, apalagi kalau bukan Pancasila.

Bahkan Horkheimer menuding rasionalitas masyarakat modern sebagai rasionalitas instrumental. Manusia modern hanya menjadi menjadi budak hasrat untuk menguasai dan memperalat dunia. Dengan modus seperti itu, manusia hanya berurusan dengan klasifikasi dan verifikasi fakta-fakta, sementara yang berkaitan dengan nilai-nilai emansipatoris-kemanusiaan dianggap tidak bermakna. ${ }^{8}$

Dengan berpegang pada Pancasila sebagai paradigma kebangsaan, tentu ini perkara keyakinan, nilai, cita-cita, dan perasaan otentik yang menjadi landasan sikap hidup bangsa Indonesia. Hal ini bukan tanpa alasan,

\footnotetext{
8 Husain Heriyanto, 2003, Paradigma Holistik "Dialog Filsafat, Sains, dan Kehidupan, Menurut Shadra dan Whitehead, Jakarta, Teraju, hlm. 81.
} 
hakikat manusia ${ }^{9}$ merupakan basis ontologis dari Pancasila. Maka memiliki implikasi terhadap bangunan epistemologi yang mendasar terkait filsafat manusia tentang sumber pengetahuan manusia. Sebagaimana sumber pengetahuan Pancasila adalah nilai-nilai yang ada pada bangsanya sendiri, dengan kata lain bahwa bangsa Indonesia merupakan kausa materialis Pancasila. $^{10}$ Sila-sila sebagai suatu sistem filsafat juga memiliki satu kesatuan dasar aksiologisnya, sehingga nilai-nilai yang terkandung dalam Pancasila pada hakikatnya merupakan satu kesatuan pengetahuan empiris yang bersifat positif dan juga pengetahuan yang bersumber pada intuisi.

\section{PENUTUP}

\section{Simpulan}

Konsekuensi dari itu semua, sejatinya Pancasila merupakan perasaan otentik paradigma kebangsaaan yang mesti secara terus-

\footnotetext{
${ }^{9}$ Maka konsepsi dasar ontologis sila-sila Pancasila yaitu hakikat manusia monopluralis yaitu hakikat manusia yang memiliki unsur-unsur pokok susunan kodrat atas raga (jasmani) yaitu fisis anorganis dan jiwa (rokhani) yaitu akal. rasa yaitu potensi jiwa manusia pada tingkatan kemampuan estetis (keindahan) serta kehendak pada tingkatan (moral atau etika). Kaelan, 2010, Pendidikan Pancasila, Yogyakarta, Paradigma, hlm. 69.

10 Oleh karena sumber pengetahuan Pancasila adalah bangsa Indonesia yang memiliki nilai-nilai adat istiadat serta kebudayaan dan nilai religius. Ibid.
}

menerus dipertahankan dan mewariskan nilai-nilai itu pada kesadaran logis dengan refleksi yang intuitif. Penghayatan holistik akan menjadi pengembangan nilai-nilai Pancasila sebagai paradigma kebangsaan yang tidak semata-mata sebagai akumulasi informasi, tapi yang paling hakiki membentuk cara berfikir dan bersikap dalam menakar kedaulatan bangsanya.

\section{DAFTAR PUSTAKA}

Heriyanto Husain, 2003, Paradigma Holistik "Dialog Filsafat, Sains, dan Kehidupan, Menurut Shadra dan Whitehead, Jakarta, Teraju. Hardiman Budi F., 2013, Kritik Ideologi "Menyikap Pertautan Pengetahuan dan kepentingan Bersama Jurgen Habermas, Yogyakarta, Kanisius.

Kaelan, 2010, Pendidikan Pancasila, Yogyakarta, Paradigma.

Susanto Anthon, 2010, Ilmu Hukum Non Sistematik "Fondasi Filsafat Pengembangan Ilmu Hukum 
Progresif: Jurnal Hukum Volume XIII/No.1/ Juni 2019 Toni \& Faisal, Pancasila: Antara........

Indonesia”, Yogyakarta, Genta

Publishing.

Samekto Adji, 2012, Ilmu Hukum dalam

$$
\text { Perkembangan Pemikiran }
$$

Menuu Post-Modernisme,

Lampung, Indepth Publishing.

Wilardjo Liek, 1990, Realita dan

Desiderata, Yogyakarta, Duta Wacana

University Press 